\section{Russian presidential favourite pledges support for science}

\section{Moscow}

Vladimir Putin, Russia's acting president and prime minister, said last week that scientists "must get salaries higher than anyone else in the country".

Speaking during a visit to

Zelenograd, a town outside Moscow that is known as Russia's 'Silicon Valley', Putin said that "if a country lacks a working economy, it has no present, but if it lacks a competitive science, it will never have a future".

The visit took place on 8 February, the date on which Peter the Great signed his decree founding the Russian Academy of Sciences in 1724, and which was designated last year as the annual Day of Russian Science by then president Boris Yeltsin.

In a bid to demonstrate that the new administration has a keen interest in science, many of the nation's top officials were present.

In an address, Putin said that the process of acknowledging the economic and strategic importance of science had already started. He pointed out that last year, for the first time in a decade, all the money allocated to science in the state budget had been paid.

He added that he was confident that this current year would see a breakthrough in funding for science.

Science provided the United States with 20 per cent of all its wealth, but Russia with less than 1 per cent. "The major problem here is an abyss between science and its implementation," said Putin. "As time passes, we are still unable to derive benefits from our own ideas."

Although stopping short of promising a substantial increase in the science budget, he suggested that the whole approach to raising money for research should be changed. It needed to be multichannel and to make effective use of intellectual property. Most important, said Putin, was that scientists should remember that the "real value of their research is confirmed by the market".

On the eve of his visit to Zelenograd, Putin met privately with Yuri Osipov, president of the Russian Academy of Sciences, a move which suggests that real reforms may be implemented. The planned science budget for the year 2000 is already 40 per cent higher than last year, with a high proportion of this being allocated to basic research. But the total science budget is just 15.9 billion rubles (\$550 million).

Carl Levitin

\title{
Republican candidates clash on fetal tissue in research
}

\section{Washington}

As George W. Bush, the governor of Texas, and Arizona senator John McCain prepare to contest the Republican primary in South Carolina on 19 February, the controversial issue of government-funded fetal-tissue research is emerging as a flashpoint in the race for the presidential nomination.

The National Right to Life Committee (NRLC), the nation's largest anti-abortion group, is running radio advertisements attacking McCain for reversing his opposition to government funding of such research. In a series of Senate votes between 1992 and 1997, McCain supported the research, even though he had opposed it up to 1992.

Bush is capitalizing on the issue. "Governor Bush is opposed to federal funding for medical research involving aborted fetuses," says Scott McClellan, Bush's press secretary. "It's up to Senator McCain to explain why he changed his position."

But supporters of the research charge that Bush and the NRLC are distorting McCain's position. "A vote on fetal-tissue research is not a pro-abortion vote," says Joan Samuelson, president of the Parkinson's Action Network.

McCain has said that he was moved to change his position by the plight of his close friend, the late Arizona Congressman Morris Udall, who died from Parkinson's disease.

"I've been convinced that [fetal-tissue research is] promising... a way to find a cure

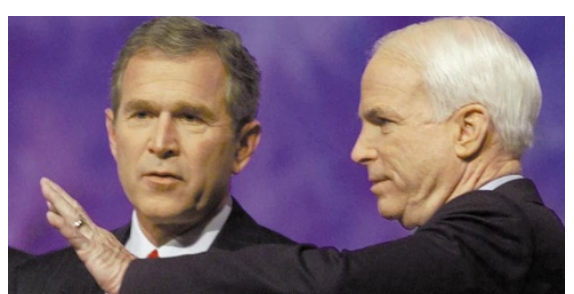

At odds: McCain (right) takes a more liberal stance than his rival Bush.

for a terrible disease. And I made no secret of my changing my position," McCain said on ABC television's This Week on 6 February. "I'm not supporting abortion to provide it."

But in a letter written to an anti-abortion constituent in 1998, McCain said that "I am appalled, as you are, at the prospect of induced abortions becoming an accepted practice, even if it is in the interest of 'furthering medicine"'.

Apart from the issue of fetal-tissue research, McCain's voting record has otherwise been strongly anti-abortion. For example, he was among 20 senators who signed a 4 Februaryletter asking the National Institutes of Health to withdraw its proposal to fund research on human stem cells derived from embryos left over after fertility treatments.

McCain is among several high-profile Republican senators who oppose abortion but have supported federal funding of fetal-tissue research.

Meredith Wadman

\section{Funding crisis for Indian biotech centre}

New Delhi

An international centre set up in India 12 years ago by the United Nations Industrial Development Organization (UNIDO) to bring the benefits of biotechnology to developing countries is facing a financial crisis.

"The future is grim," says Virender Singh Chauhan, chief executive of the New Delhi component of the International Centre for Genetic Engineering and Biotechnology (ICGEB). Grants for his unit have been cut by 10 per cent this year, and support is expected to be reducd by about 25 per cent by 2001 .

The ICGEB, whose rules and regulations have been ratified by the governments of 61 countries, operates from two locations, in New Delhi and at Trieste in Italy.

It had been hoped that the centre would raise money from members' contributions, grants from research foundations, the commercialization of technologies it develops, and support from India and Italy.
According to Chauhan, the recent budget cuts were forced by the member states refusing to pay their contributions.

Non-payment by member states has not affected the Trieste unit, as the Italian government has doubled its contribution, says Chauhan. The New Delhi unit is surviving on an annual contribution of US\$1.25 million from the Indian government and grants from ICGEB headquarters in Italy. But the grants have been cut, and the Indian government is not willing to increase its contribution.

The crisis has already taken its toll of research programmes. Recruitment has been halted, and 16 scientists have already left, with 10 more likely to follow.

Chauhan says that so far only middle-level researchers have left, but that senior scientists may leave if the situation does not improve. The number of scientists trained by ICGEB has also fallen as funding for training programmes been reduced, he says. $\mathbf{K}$. S. Jayaraman 